\title{
INKLUSI KEUANGAN DAN LITERASI KEUANGAN TERHADAP KINERJA DAN KEBERLANJUTAN UMKM DI SOLO RAYA
}

\author{
Melia Kusuma $^{1}$, Devi Narulitasari' ${ }^{2}$, Yulfan Arif Nurohman ${ }^{3}$ \\ 1,2,3Fakultas Ekonomi dan Bisnis Islam, Universitas Raden Mas Said Surakarta \\ ${ }^{1}$ melia.dosen@gmail.com \\ 2devina_ede@yahoo.com \\ 3yulfanan@gmail.com
}

\begin{abstract}
ABSTRAK
Usaha Mikro Kecil dan Menengah (UMKM) mengalami berbagai macam persoalan pada masa pandemi covid-19. Adapun persoalan yang dihadapi oleh UMKM berkaitan dengan permodalan dan keberlanjutan usaha akibat adanya pembatasan kegiatan masyarakat yang berdampak terhadap penurunan tingkat pendapatan. Penelitian ini bertujuan untuk menguji pengaruh inklusi keuangan dan literasi keuangan terhadap kinerja usaha dan keberlanjutan UMKM di Solo Raya. Penelitian yang dilakukan menggunakan pendekatan kuantitatif dengan memberikan kuesioner kepada responden. Adapun teknik pengambilan sampel menggunakan purposive sampling dengan memberikan pertimbangan berupa responden UMKM di Solo Raya yang sudah berdiri lebih dari satu tahun dan masih aktif menjalankan usaha. Teknik analisa data yang dilakukan menggunakan Partial Least Square (PLS). Hasil pengujian menunjukan bahwa inklusi keuangan berpengaruh terhadap keberlanjutan usaha dan kinerja keuangan UMKM, serta literasi keuangan berpengaruh terhadap kinerja keuangan pada UMKM di Solo Raya. Sedangkan variablel literasi keuangan tidak berpengaruh terhadap keberlanjutan usaha pada UMKM di Solo Raya.
\end{abstract}

Kata kunci: inklusi keuangan, literasi keuangan, keberlanjutan usaha, kinerja UMKM.

\section{PENDAHULUAN}

UMKM menjadi bagian yang sangat terpukul dan terdampak oleh adanya pandemi covid-19 di Indonesia (Thaha, 2020). Berbagai upaya dilakukan pemerintah untuk menghentikan penyebaran virus covid-19. Kebijakan yang diambil pemerintah dengan menerapkan Pembatasan Sosial Berskala Besar (PSBB), Pemberlakuan Pembatasan Kegiatan Masyarakat (PPMKM) Jawa-Bali, PPKM Mikro, Penebalan PPKM Mikro, PPKM Darurat, hingga PPKM Level 3 dan 4 yang diterapkan pada bulan Juli 2021 (Tempo, 2021). Kebijakan ini membuat masyarakat tidak dapat melakukan aktivitas seperti kondisi normal. Pembatasan kegiatan menyebabkan masyarakat mengalami kesulitan dalam beraktivitas. Keinginan mendapatkan produk dan jasa terhalang oleh pemberlakukan pembatasan kegiatan masyarakat dalam upaya mengurangi penyebaran virus covid-19. Pelaku sektor UMKM memiliki waktu operasional yang terbatas dalam melayani masyarakat. Kemampuan UMKM dalam memenuhi kebutuhan dan keinginan masyarakat terbatasi oleh kebijakan yang ditempuh dalam mengurangi penyebaran virus covid-19. Keterbatasan tersebut menyebabkan pendapatan keuangan UMKM mengalami penurunan.

ISSN : 1979-7400

E-ISSN: 2774-5163 
Beberapa upaya yang telah dilakukan pemerintah dalam pemulihan ekonomi terlihat masih banyak terpusat pada sektor pariwisata. Bantuan atau insentif perlu diperhatikan apalagi mengingat himbauan social distancing saat ini yang berpengaruh besar pada UMKM (Bahtiar \& Saragih, 2020). Meskipun UMKM dalam kondisi mengkhawatirkan, fakta mengejutkan ialah sektor UMKM justru penyumbang terbesar ke produk domestik bruto (PDB) Indonesia, yakni mencapai $60 \%$ dimasa pandemi covid19 (Julaika, 2020). Artinya keberadaan UMKM di Indonesia dianggap penting karena mampu bertahan dan menyumbangkan produk domestik bruto (PDB) dalam jumlah yang besar. UMKM memang mendapatkan perhatian khusus dari pemerintah, baik sebelum pandemi covid-19 maupun saat terjadi pandemi covid-19.

Keberadaan UMKM sangat membantu mengurangi tingkat pengangguran dan kemiskinan. Berdasarkan data Bank Indonesia pada tahun 2015, sektor UMKM menyerap tenaga kerja sekitar 97\% dari seluruh tenaga kerja Indonesia dan memberikan kontribusi sebesar 60\% terhadap Produk Domestik Bruto. Pada bulan Februari 2021, tercatat 8,75 juta pengangguran di Indonesia. Jumlah tersebut meningkat 26,26\% dibandingkan periode yang sama tahun 2020 yakni sejumlah 6,93 juta orang (BPS, 2021). Jumlah pengangguran yang meningkat disebabkan oleh pemutusan hubungan kerja yang dilakukan oleh perusahaan terdampak pandemi covid-19. Perusahaan tidak mampu menanggung kerugian dengan memberikan gaji kepada karyawan, sedangkan pada sisi lain pendapatan perusahaan berkurang cukup signifikan. Pengurangan karyawan menjadi opsi paling mudah bagi perusahaan untuk mengurangi potensi kerugian yang lebih besar dimasa mendatang.

Tabel 1 : Tingkat Pengangguran Terbuka

\begin{tabular}{lcc}
\hline \multicolumn{1}{c}{ Bulan } & Tahun & Jumlah (Orang) \\
\hline Februari & 2021 & 8,7 Juta \\
Agustus & 2020 & 9,8 Juta \\
Februari & 2020 & 6,9 Juta \\
Agustus & 2019 & 7 Juta \\
Februari & 2019 & 6,8 Juta \\
Agustus & 2018 & 7 Juta \\
Februari & 2018 & 6,9 Juta \\
Agustus & 2017 & 7 Juta \\
Februari & 2017 & 7 Juta \\
Agustus & 2016 & 7 Juta \\
Februari & 2016 & 7 Juta \\
\hline
\end{tabular}

Sumber: BPS (2021)

Bagi pelaku sektor UMKM sangat penting untuk memahami dan memiliki pengetahuan tentang inklusi keuangan dan literasi keuangan. Hal ini disebabkan inklusi keuangan dan literasi keuangan berpengaruh terhadap pengelolaan keuangan yang akan memberikan dampak terhadap kinerja dan keberlangsungan UMKM (Desiyanti, 2016). Pemahaman dan pengetahuan keuangan yang baik, pengelolaan keuangan UMKM dapat berjalan optimal. Masa pandemi menyebabkan penurunan pendapatan bagi pelaku UMKM (Santika \& Maulana, 2020). Hal ini ditunjukan hasil survei oleh Soetjipto (2020) bahwa sebanyak $96 \%$ pelaku usaha sudah mengalami dampak negatif pandemi covid-19 pada kegiatan bisnis yang dijalani sebesar 1.785 koperasi dan 163.713 pelaku UMKM. Sebesar 75\% mengalami dampak penurunan penjualan yang signifikan.

Menurut Malik (2021) bahwa Otoritas Jasa Keuangan menyampaikan hasil survei salah satu bank internasional pada 2020 menyebutkan generasi milenial berusia 25-44

ISSN : 1979-7400

E-ISSN: 2774-5163 
tahun menjadi generasi yang paling terkena dampak pandemi covid-19 dari sisi finansial. Tirta Segara selaku Anggota Dewan Komisioner OJK Bidang Edukasi dan Perlindungan Konsumen menyampaikan diperlukan program literasi dan edukasi keuangan menjadi semakin penting dan krusial di masa pandemi terutama bagi Generasi Z dan Milenial. Literasi Keuangan yang baik akan mempercepat pemulihan ekonomi nasional.

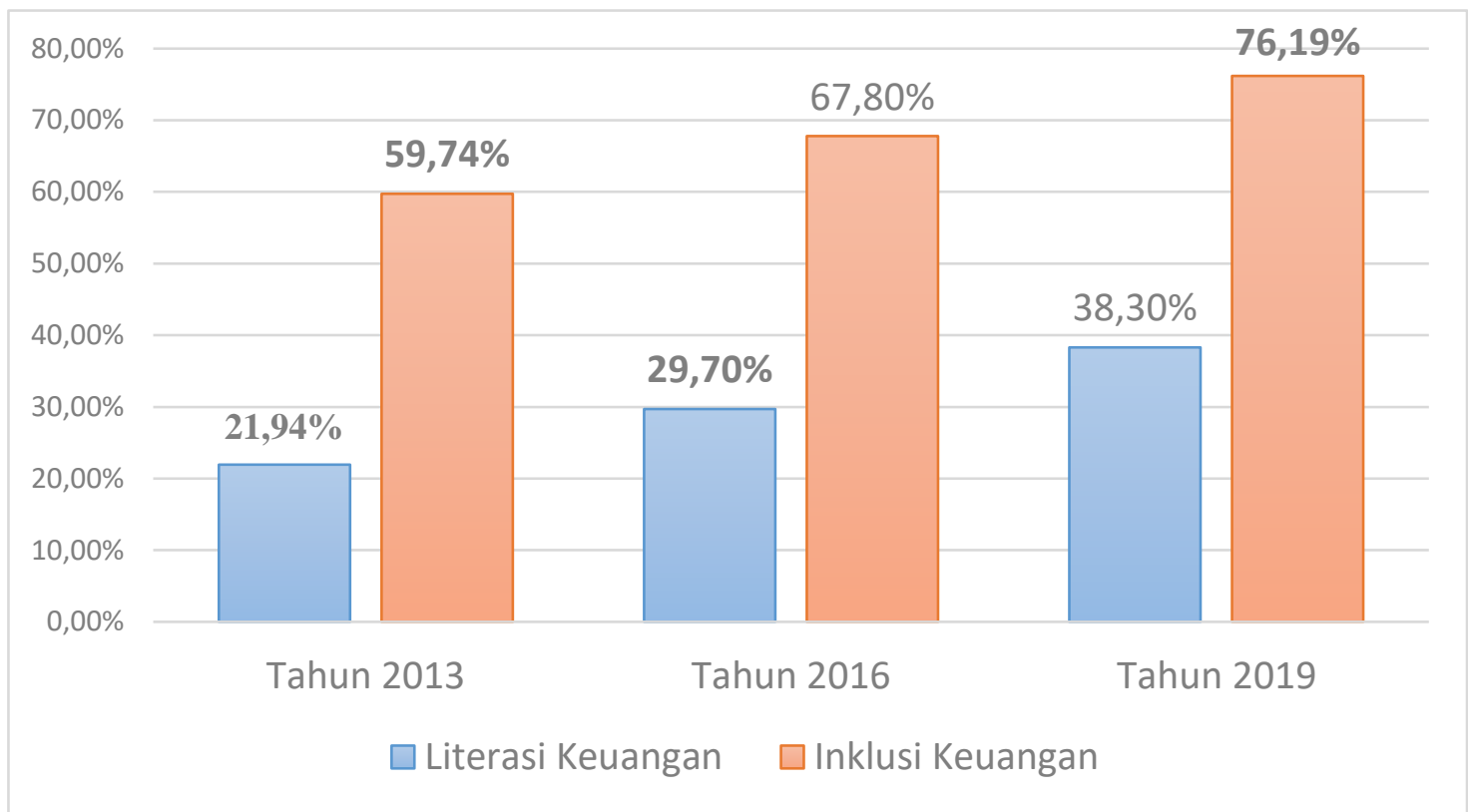

Gambar 1. Grafik Indeks Literasi dan Inklusi Keuangan Nasional Sumber: OJK (2020)

Indeks literasi dan inklusi keuangan nasional menunjukan bahwa terjadi peningkatan. Pada tahun 2013, literasi keuangan nasional sebesar 21,94\% menjadi $29,70 \%$ pada tahun 2016 , dan sebesar $38,30 \%$ pada tahun 2019. Sedangkan inklusi keuangan juga mengalami peningkatan seperti literasi keuangan, dimulai 59,74\% pada tahun 2013 meningkat menjadi 67,80\% pada tahun 2016, dan sebesar 76\% pada tahun 2019. Peningkatan literasi dan inklusi keuangan merupakan hal positif bagi Indonesia, terutama bagi pelaku UMKM. Pemerintah berupaya agar literasi keuangan dan inklusi keuangan masyarakat terus meningkat. Berdasarkan survei yang dilakukan di Solo oleh OJK pada tahun 2019, diketahui bahwa tingkat literasi keuangan sebesar 26\% dan tingkat inklusi keuangan sebesar 48,9\%. Hal tersebut menunjukan tingkat literasi dan inklusi keuangan di Solo dianggap masih minim. Kantor Perwakilan (KPw) Bank Indonesia Solo dan Rumah Zakat melaksanakan pelatihan dan pendampingan pengelolaan keuangan pribadi dan usaha dengan tujuan meningkatkan kesejahteraan pelaku usaha UMKM dan peningkatan literasi keuangan masyarakat (Republika, 2021).

Agar mampu berperan kembali dalam membantu mengurangi tingkat pengangguran dan kemiskinan, maka perlu dilakukan peningkatan kinerja dan keberlanjutan sektor UMKM di Indonesia. Permasalahan utama dalam UMKM adalah dalam hal permodalan dan pemasaran. Salah satu cara yang dapat digunakan untuk mengatasi masalah tersebut adalah dengan menerapkan model inklusi keuangan (Irmawati, 2013). Hasil penelitian Sanistasya et al., (2019) bahwa literasi keuangan dan inklusi keuangan mampu meningkatkan kinerja UMKM. Sedangkan inklusi keuangan

ISSN : 1979-7400 
mampu membantu keberlangsungan usaha sektor UMKM dalam jangka waktu yang lama (Nurohman et al., 2021; Wise, 2013; Le et al., 2019). Namun hasil penelitian yang berbeda dari Hilmawati \& Kusumaningtias, (2021) menyatakan bahwa inklusi keuangan tidak berpengaruh terhadap kinerja dan keberlangsungan UMKM di Kota Surabaya.

Berdasarkan permasalahan diatas, maka tujuan penelitian ini adalah sebagai berikut:

1. Mengetahui pengaruh pengaruh inklusi keuangan terhadap kinerja UMKM di Solo Raya

2. Mengetahui pengaruh pengaruh inklusi keuangan terhadap keberlanjutan UMKM di Solo Raya

3. Mengetahui pengaruh pengaruh literasi keuangan terhadap kinerja UMKM di Solo Raya

4. Mengetahui pengaruh pengaruh literasi keuangan terhadap keberlanjutan UMKM di Solo Raya

\section{LANDASAN TEORI DAN PENGEMBANGAN HIPOTESIS}

\section{Inklusi Keuangan}

World Bank merumuskan inklusi keuangan merupakan kemudahan bagi individu dan unit bisnis untuk memiliki akses dan produk keuangan yang berguna dan terjangkau untuk memenuhi kebutuhan dengan cara yang bertanggung jawab. Pemahaman keuangan bagi pelaku UMKM mempermudah dalam pengelolaan dan mengakses produk keuangan. Inklusi keuangan dianggap sebagai proses yang memudahkan akses, ketersediaan, dan manfaat dari sistem keuangan formal bagi seluruh pelaku ekonomi (Sarma, 2012). Bank Indonesia (2013) mendefinisikan inklusi keuangan sebagai seluruh upaya yang bertujuan menjadikan segala bentuk hambatan yang bersifat harga maupun non harga, terhadap akses masyarakat dalam memanfaatkan layanan jasa keuangan.

Menurut Peraturan yang diterbitkan oleh Otoritas Jasa Keuangan pada tahun 2017, memberikan pernyataan tentang pengertian inklusi keuangan yang memiliki arti ketersediaan akses bagi beberapa lembaga, produk, dan layanan jasa keuangan sesuai dengan kebutuhan dan kemampuan masyarakat dalam meningkatkan kesejahteraan masyarakat. Berdasarkan pernyataan Center for Financial Inclusion memberikan pengertian tentang inklusi keuangan yang berarti akses terhadap produk keuangan yang sesuai, seperti pembiayaan, tabungan, asuransi, dan pembayaran. Ketersediaan akses yang berkualitas menurut Center for Financial Inclusion terdiri dari kenyamanan, jangkauan, kesesuaian, perlindungan, dan ketersediaan terhadap pelayanan kepada masyarakat. Ketersediaan pelayanan atau kebutuhan keuangan mampu memberikan bantuan kepada pelaku UMKM untuk memenuhi kecukupan permodalan. Hambatan dan permasalahan bagi UMKM ialah berkaitan dengan permodalan, sehingga ketersediaan jasa pembiayaan bagi UMKM dapat membantu keberlanjutan usaha. Menurut Strategi Nasional Literasi Keuangan Indonesia (2017), prinsip dasar inklusi keuangan terdiri dari: a. Terukur

Upaya meningkatkan inklusi keuangan dilakukan dengan memberikan pertiumbangan terhadap keterjangkauan lokasi, biaya, waktu, sistem teknologi, mitigasi risiko dalam setiap transaksi atau akses keuangan yang dilakukan oleh masyarakat. 
b. Terjangkau

Pelaksanaan peningkatan inklusi keuangan dengan memberika akses bagi masyarakat untuk mudah mendapatkan pelayanan keuangan.

c. Tepat sasaran

Pelaksanaan peningkatan inklusi keuangan sesuai dengan kebutuhan masyarakat dan sasaran yang telah ditetapkan.

d. Keberlanjutan

Peningkatan inklusi keuangan untuk mendapatkan kesinambungan dan keberlanjutan usaha yang dilakukan oleh pelaku UMKM maupun masyarakat pada umumnya.

Hipotesis 1 (H1): Inklusi keuangan berpengaruh terhadap Keberlanjutan UMKM di Solo Raya

Akses terhadap pelayanan perbankan menjadi bagian yang penting pertumbuhan ekonomi. Pelayanan perbankan yang mudah diakses dapat menarik minat pelaku UMKM dalam melakukan akses perbankan seperti meminjam dan menabung. Kemudahan akses perbankan diharapkan dapat membangun aset dan membantu kegiatan UMKM. Inklusi keuangan diharapkan mampu meningkatkan taraf hidup masyarakat secara keseluruhan (Klapper, 2012). Peningkatan taraf hidup masyarakat dapat dicapai ketika kinerja UMKM sesuai dengan program yang telah dilakukan oleh pelaku usaha, sehingga harapan keuntungan dapat terwujud sesuai program usaha yang telah ditetapkan. Berdasarkan Otoritas Jasa Keuangan pada tahun 2017, inklusi keuangan memiliki tujuan sebagai berikut:

a. Meningkatkan akses masyarakat terhadap lembaga, produk, dan layanan jasa keuangan

b. Meningkatkan produk dan jasa keuangan terhadap masyarakat sesuai kemampuan yang dimiliki

c. Meningkatkan penggunaan produk dan jasa keuangan sesuai kebutuhan dan kemampuan masyarakat

d. Meningkatkan pemanfaatkan kualitas produk dan jasa keuangan sesuai kebutuhan dan kemampuan masyarakat

Tingkat literasi yang dimiliki oleh seseorang serta akses terhadap berbagai produk keuangan akan memengaruhi pengelolaan keuangan pribadi maupun keuangan perusahaan. Keputusan yang dilakukan oleh individu maupun pelaku bisnis berkaitan dengan keputusan investasi dimasa depan. Upaya untuk meningkatkan kondisi keuangan dilakukan oleh pelaku usaha dengan membuat investasi dan ekspansi usaha. Pelaku usaha yang mampu mengelola UMKM dapat meningkatkan kondisi usaha meliputi perluasan usaha dan kondisi keuangan.

Hipotesis 2 (H2): Inklusi keuangan berpengaruh terhadap Kinerja UMKM di Solo Raya

\section{Literasi Keuangan}

Literasi keuangan merupakan faktor yang fundamental untuk pertumbuhan ekonomi dan stabilitas keuangan (INFE, 2012). Pelaku UMKM membutuhkan pengetahuan keuangan untuk mendapatkan kesejateraan dari bidang usaha yang dijalankan. Kebutuhan literasi keuangan sejak dini perlu dipenuhi untuk mendapatkan kesejahteraan dimasa depan (Rapih, 2016). Pengetahuan literasi keuangan tidak lepas dari pengetahuan keuangan. Kondisi dan latar belakang pelaku UMKM membuat tingkat literasi keuangan berbeda-beda. Literasi keuangan memiliki esensi yang lebih mendetail dibandingkan pengetahuan keuangan. Pemahaman secara mendetail dapat memberikan ISSN : 1979-7400 
keputusan keuangan yang tepat. Huston (2010) menyatakan pengetahuan keuangan merupakan dimensi yang tidak dapat terpisahkan dengan literasi keuangan, akan tetapi pengetahuan tersebut belum dapat menggambarkan literasi keuangan. Pelaku UMKM tidak hanya memiliki pengetahuan keuangan, tetapi juga memiliki kemampuan dalam mengaplikasikan pengetahuan keuangan (Lusardi, A \& Mitchell, 2007).

Dewi et al., (2018) menyatakan bahwa literasi keuangan sangat erat kaitannya dengan pengelolaan keuangan individu atau pribadi yang meliputi keputusan investasi, pendanaan, dan pengelolaan aset. Diadaptasi dari USAID (2009), pemilik atau manajer UMKM yang melek finansial didefinisikan sebagai seseorang yang tahu apa keputusan pembiayaan yang paling sesuai untuk kinerja bisnisnya di berbagai tahap pertumbuhan bisnis, serta mengetahui di mana mendapatkan produk dan layanan yang paling sesuai dan berinteraksi dengan keyakinan dengan pemasok produk dan layanan ini (Remund, 2010). Berdasarkan pernyataan Fenwick et al., (2018) mengemukakan bahwa literasi keuangan merupakan keadaan di mana seseorang mampu membuat penilaian yang diinformasikan dan secara efektif dapat membuat keputusan terkait dengan penggunaan dan pengelolaan uang. Ini mengacu pada kemampuan untuk menguasai seperangkat pengetahuan, sikap dan perilaku tentang masalah keuangan. Termasuk memiliki sikap yang memfasilitasi pengelolaan urusan keuangan secara efektif dan bertanggung jawab. Literasi keuangan juga merupakan kemampuan membaca, menganalisis, mengkomunikasikan, dan mengelola kondisi keuangan yang berdampak pada kesejahteraan umum mereka dan mampu dengan nyaman membedakan pilihan keuangan, berdiskusi uang dan masalah keuangan lainnya.

Terdapat beberapa penelitian yang menunjukkan bahwa literasi keuangan berhubungan positif dengan kinerja perusahaan (Huston, 2010). Perusahaan yang melek keuangan memiliki wawasan yang lebih baik tentang aspek keuangan dari masalah strategis sehingga kinerjanya lebih baik. Davidson et al. (2004) menemukan adanya hubungan antara literasi keuangan dan kinerja perusahaan. Selanjutnya, literasi keuangan dikenal sebagai faktor penting dalam akumulasi kekayaan, serta kinerja perusahaan (Behrman et al., 2012). Perusahaan yang melek keuangan lebih cenderung menerapkan praktik manajemen keuangan yang baik yang akan meningkatkan kinerja dan keberlanjutan mereka. Dengan demikian, literasi keuangan dianggap berdampak positif terhadap keberlanjutan UMKM.

Hipotesis 3 (H3): Literasi keuangan berpengaruh terhadap Keberlanjutan UMKM di Solo Raya

Organization for Economic Co-operation and Development (2016) menyatakan instrumen yang digunakan dalam pengukuran tingkat literasi keuangan, yaitu:

a. Pengetahuan keuangan (financial knowledge), tingkat pengetahuan keuangan pelaku UMKM dapat diukur berdasarkan pengetahuan tentang nilai waktu dari uang, bunga pinjaman, prinsip perhitungan bunga bank, bunga majemuk, risiko dan laba, inflasi, dan diversifikasi.

b. Perilaku keuangan (financial behaviour), pola pelaku UMKM dalam menyikapi keuangan dapat diukur dengan pertimbangan dalam memutuskan pembelian, ketepatan waktu membayar tagihan, pengelolaan dan pengaturan keuangan masa depan, kegiatan menyimpan uang, keputusan dalam memilih produk keuangan, dan pinjaman yang dilakukan dalam memenuhi kebutuhan.

c. Sikap keuangan (financial attitude), sikap pelaku UMKM diukur menggunakan orientasi terhadap keuangan pribadi, filsafat utang, tingkat keamanan keuangan, dan menilai keuangan pribadi.

ISSN : 1979-7400

E-ISSN: 2774-5163 


\section{Keberlangsungan dan Kinerja Usaha}

Keberlanjutan usaha (business sustanbility) pada UMKM dapat diketahui berdasarkan keberhasilan pelaku usaha dalam melakukan inovasi, pengelolaan karyawan dan konsumen serta pengembalian terhadap modal yang digunakan dari awal. Hal ini menunjukan bahwa UMKM memilik iorientasi untuk berkembang dan melihat peluang untuk inovasi secara berkesinambungan (Hudson, M., 2001). Indikator pada keberlangsungan usaha terdiri dari pertumbuhan keuangan, pertumbuhan strategi, pertumbuhan struktural, dan pertumbuhan organisasional. Dimana indikator tersebut dapat digunakan dalam mengukur keberhasilan pengusaha dalam melaksanakan keberlajutan UMKM (Wickham, 2006).

Kinerja perusahaan adalah cerminan dari kemampuan perusahaan untuk menciptakan nilai, baik dari perspektif finansial maupun non-finansial (Hudson et al., 2001). Perspektif keuangan adalah kemampuan perusahaan untuk meningkatkan kesejahteraan pemegang saham melalui laba yang dihasilkan, sedangkan perspektif nonkeuangan adalah kemampuan perusahaan untuk menciptakan nilai-nilai positif seperti kinerja lingkungan, dan tanggung jawab sosial. Dengan demikian, perusahaan dikatakan memiliki kinerja yang sangat baik jika kedua kinerja ini menunjukkan nilai yang lebih baik, artinya dari sisi finansial pertama, tetapi juga tidak melupakan aspek non keuangan.

Sementara itu, kesinambungan adalah kemampuan perusahaan untuk terus menjalankan bisnis. Menurut Eresia-Eke \& Raath (2013) UMKM yang memiliki keberlanjutan bisnis adalah UMKM yang selalu mengalami pertumbuhan dari waktu ke waktu. Artinya, jika UMKM mengalami stagnasi bisnis, maka dapat dipastikan bahwa UMKM tersebut tidak dapat melanjutkan bisnisnya. Dalam penelitian yang dilakukan oleh Ali (2003) menyatakan bahwa pengukuran kinerja UMKM dapat dilakukan menggunakan asumsi sebagaimana berikut ini:

a. Pengukuran kinerja berdasarkan pemahaman keuangan dan tenaga kerja

b. Pengukuran kinerja berdasarkan indikator keuangan untuk menunjukan kondisi aktual UMKM

c. Pengukuran kinerja berdasarkan kondisi manajemen UMKM

Maka berdasarkan pendekatan non-cost performance measures yang digunakan dalam penelitian ini untuk mengukur kinerja UMKM sebagai pengukuran kinerja keuangan dan non keuangan UMKM. Adapun pengukuran yang mudah (melalui persepsi) diharapkan mampu memperlihatkan kondisi sebenarnya dari UMKM tersebut, selain itu perlu dilakukan edukasi untuk menghitung kinerja perusahaan dengan indikator yang mudah seperti company's growth, company's total revenue (sales), total orders dan cash position.

Beberapa literatur menurut Florido et al., (2015) dan Hogeforster (2014) mengidentifikasi alat yang berbeda dalam menentukan kinerja UMKM. Mayoritas studi mempertimbangkan tingkat inovasi dalam produk, proses, dan sistem manajemen, dan kelangsungan hidup dan daya saing UMKM sebagai indikator kritis. Duygulu et al., (2016) mencatat tiga komponen misi dalam menilai kinerja UMKM: (1) kelangsungan hidup, pertumbuhan, dan keuntungan, (2) filosofi dan nilai, dan (3) citra publik. Hasil dari kinerja UMKM yang lebih baik dapat divisualisasikan dalam perekonomian melalui peningkatan pendapatan industri, penciptaan lapangan kerja, peningkatan pertumbuhan ekspor, dan peningkatan produktivitas.

\section{Hipotesis 4 (H4) Literasi keuangan berpengaruh terhadap Kinerja UMKM di Solo Raya}

ISSN : 1979-7400

E-ISSN: 2774-5163 


\section{MODEL PENELITIAN} berikut:

Adapun model penelitian yang digunakan dalam penelitian dapat diketahui sebagai

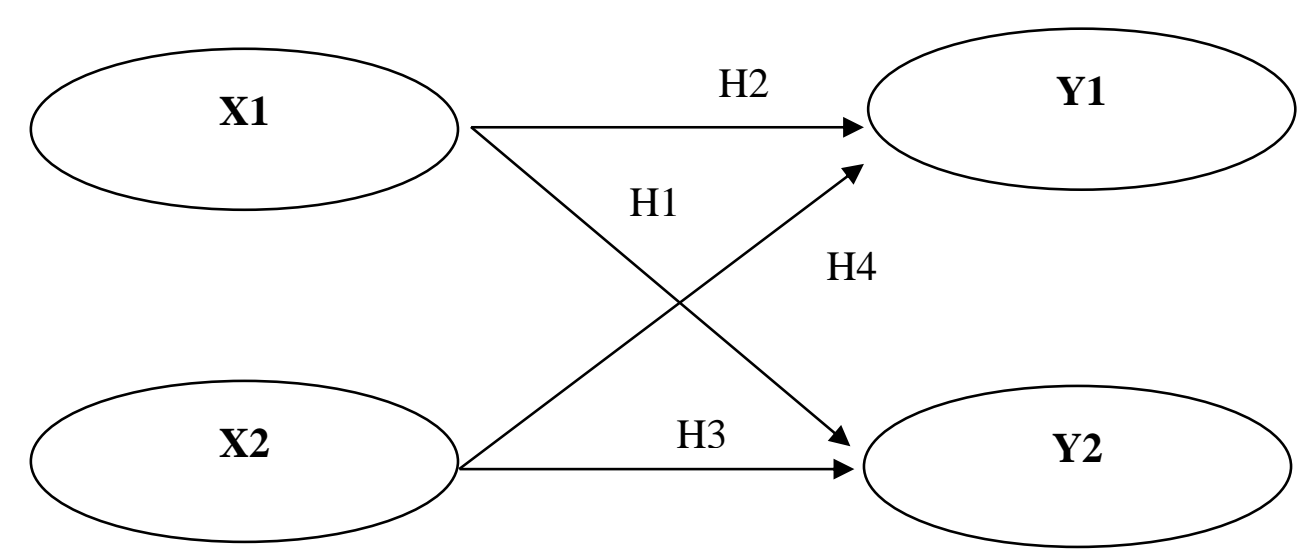

Gambar 2. Model Penelitian

Keterangan:

$\begin{array}{ll}\text { X1 } & \text { : Inklusi keuangan } \\ \mathrm{X} 2 & \text { : Literasi keuangan } \\ \text { Y1 } & \text { : Kinerja UMKM } \\ \text { Y2 } & \text { : Keberlangsungan UMKM }\end{array}$

\section{METODE PENELITIAN}

Penelitian ini dikategorikan dalam penelitian kuantitatif, dimana dalam penelitian memuat data berupa angka-angka atau dihitung secara langsung serta dapat dilakukan analisa secara statistik (Sugiyono, 2016). Pendekatan kuantitatif menggunakan pendekatan ilmiah yang diperoleh dari wawancara melalui survei berdasarkan kuesioner. Data yang diperoleh dari responden disajikan dalam skala likert yang mewakili jawaban yang diberikan. Skala likert yang digunakan menggunakan lima skor terdiri dari skor 1 merupakan jawaban sangat tidak setuju, skor 2 merupakan jawaban tidak setuju, skor 3 merupakan jawaban kurang setuju, skor 4 merupakan jawaban setuju, dan skor 5 merupakan jawaban sangat setuju.

Populasi yang digunakan dalam penelitian ini adalah UMKM yang berada di Solo Raya. Adapun sampel penelitian diperoleh berjumlah 66 UMKM yang berada di Solo Raya. Teknik pengambilan sampel yang digunakan adalah probability sampling dengan cara purposive sampling. Adapun purposive sampling merupakan proses pemilihan sampel menggunakan metode tertentu (Sugiyono, 2016). Kriteria responden atau sampel dalam penelitian ini terdiri dari:

a. UMKM berdiri lebih dari satu tahun

b. Lokasi UMKM berada di Solo Raya

c. UMKM masih aktif melangsukan kegiatan usaha

Analisa data yang dilakukan untuk memudahkan hasil penelitian agar lebih mudah dipahami. Dalam penelitian ini menggunakan Partial Least Square (PLS) untuk melakukan analisa data. Pemilihan penggunaan Partial Least Square dalam penelitian ini adalah variabel terikat yang digunakan lebih dari satu dan dianalisa langsung menggunakan indikator yang berbentuk reflektif.

ISSN : $1979-7400$

E-ISSN: 2774-5163 


\section{HASIL DAN PEMBAHASAN}

\section{Diskripsi Responden}

Berdasarkan kuesioner yang diperoleh, dapat diketahui bahwa jenis UMKM yang menjadi responden sebagaimana tabel berikut.

Tabel 2 : Jenis Usaha

\begin{tabular}{lcc}
\hline Jenis UMKM & Frekuensi & Persentase \\
\hline Toko Eceran & 21 & $31,8 \%$ \\
Usaha Manufaktur & 29 & $43,9 \%$ \\
Usaha Jasa & 16 & $24,2 \%$ \\
Total & 66 & $100 \%$ \\
\hline
\end{tabular}

Sumber: Data diolah, 2021

Dalam Tabel 2 dapat diketahui bahwa jenis UMKM terdiri dari tiga yaitu: toko eceran, usaha manufaktur, dan usaha jasa. Hasil yang diperoleh menunjukan toko eceran sebanyak 21 UMKM atau sebesar $31,8 \%$ berada dalam penelitian ini. Usaha manufaktur sebanyak 29 UMKM atau sebesar 43,9\%, sedangkan usaha jasa sebanyak 16 UMKM atau sebesar 24,2\%. Secara keseluruhan, usaha manufaktur merupakan responden terbanyak yang menjadi sampel dalam penelitian ini. Responden UMKM jasa merupakan jumlah terkecil yang menjadi responden dalam penelitian yang dilakukan.

Tabel 3 : Lokasi Usaha

\begin{tabular}{ccc}
\hline Lokasi & Frekuensi & Presentase \\
\hline Kota & 36 & $54,5 \%$ \\
Desa & 30 & $45,5 \%$ \\
Total & 66 & $100 \%$ \\
\hline
\end{tabular}

Sumber: Data diolah, 2021

Berdasarkan tabel 3 tentang lokasi usaha dapat diketahui dari total responden sebanyak 66 UMKM terdapat yang menjadi responden sebanyak 36 UMKM atau sebesar 54,5\% berada diperkotaan, sedangkan 30 UMKM atau sebesar 45,5\% berada dipedesaan. UMKM yang menjadi responden dalam penelitian ini mayoritas berada diwilayah perkotaan.

Tabel 4 : Lama Usaha

\begin{tabular}{lcc}
\hline \multicolumn{1}{c}{ Lama Usaha } & Frekuensi & Presentase \\
\hline 1-2 Tahun & 13 & $19,7 \%$ \\
2-5 Tahun & 34 & $51,5 \%$ \\
6-10 Tahun & 11 & $16,7 \%$ \\
>10 Tahun & 8 & $12,1 \%$ \\
Total & 66 & $100 \%$ \\
\hline
\end{tabular}

Sumber: Data diolah, 2021

Berdasarkan tabel 4 diatas, maka dapat diketahui bahwa lama berdirinya UMKM yang menjadi responden dalam penelitian ini terdiri dari 66 UMKM. Dimana UMKM yang berdiri selama 1-2 tahun sebanyak 13 UMKM atau sebesar 19,7\%. UMKM yang telah berdiri selama 2-5 tahun sebanyak 34 UMKM atau sebesar 51,5\%. UMKM yang telah berdiri selama 6-10 tahun sebanyak 1 UMKM atau sebesar 16,7\% dan UMKM yang telah berdiri lebih dari 10 tahun sebanyak 8 UMKM atau sebesar 12,1\%.

\section{Model Estimation}

Nilai loading factor sebesar 0,50 atau lebih dianggap memiliki validasi yang cukup kuat untuk menjelaskan konstruk laten (Hair et al, 2010). Nilai outer loading awal pada variabel Literasi Keuangan, Inklusi Keuangan, Keberlanjutan UMKM dan Kinerja UMKM dapat dilihat pada tabel 5. Menurut Yamin dan Kurniawan (2011) indikator ISSN : 1979-7400 
yang memiliki nilai loading factor antara 0.5 - 0.6 dapat diterima.

Tabel 5 : Outer Loading Awal

\begin{tabular}{|c|c|c|c|c|}
\hline & $\begin{array}{c}\text { Inklusi } \\
\text { Keuangan }\end{array}$ & Keberlanjutan & $\begin{array}{l}\text { Kinerja } \\
\text { UMKM }\end{array}$ & $\begin{array}{c}\text { Literasi } \\
\text { Keuangan }\end{array}$ \\
\hline INK1 & 0.737 & & & \\
\hline INK2 & 0.894 & & & \\
\hline INK3 & 0.879 & & & \\
\hline KBR1 & & 0.510 & & \\
\hline KBR2 & & 0.622 & & \\
\hline KBR3 & & 0.862 & & \\
\hline KBR4 & & 0.897 & & \\
\hline KNR1 & & & 0.445 & \\
\hline KNR2 & & & 0.831 & \\
\hline KNR3 & & & 0.894 & \\
\hline KNR4 & & & 0.911 & \\
\hline LIT1 & & & & 0.816 \\
\hline LIT2 & & & & 0.557 \\
\hline LIT3 & & & & 0.384 \\
\hline LIT4 & & & & 0.510 \\
\hline LIT5 & & & & 0.894 \\
\hline LIT6 & & & & 0.538 \\
\hline LIT7 & & & & 0.772 \\
\hline LIT8 & & & & 0.615 \\
\hline
\end{tabular}

Sumber: Hasil penelitian, diolah dengan Smart PLS 3.0, 2021

Indikator yang dieliminasi pada model ini ada dua yaitu KNR1 dan LIT3. Kelima indikator ini memiliki nilai loading factor dibawah 0,50. Setelah menghilangkan indikator variabel yang tidak valid dalam model, selanjutnya model kembali di kalkulasi ulang sehingga menghasilkan nilai outer loading yang baru dan dapat dilihat pada gambar path diagram final berikut ini:

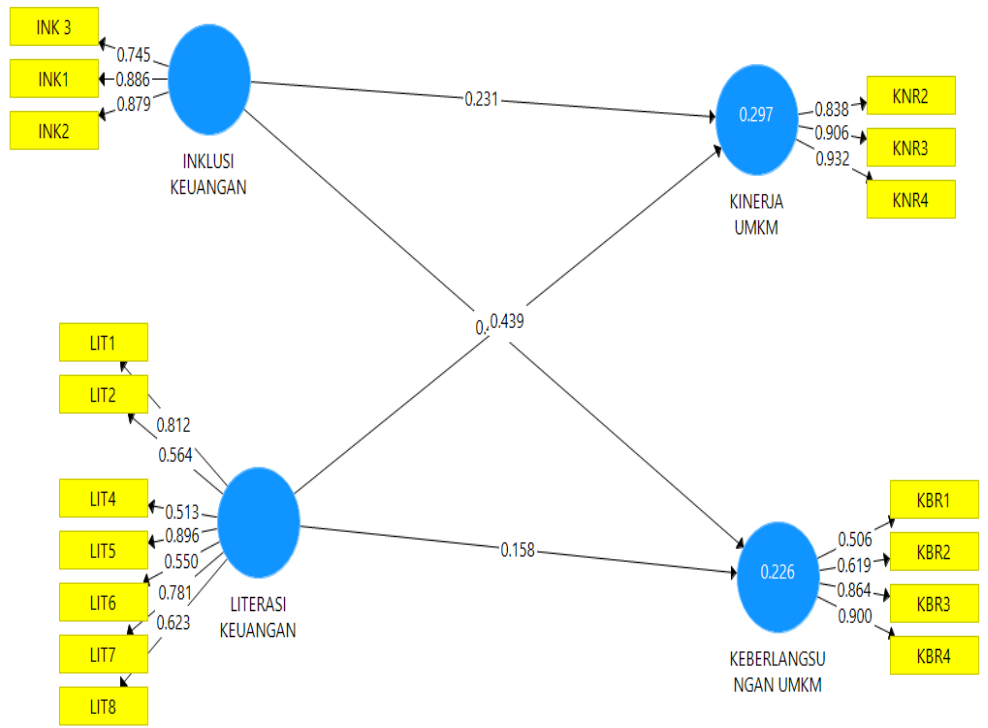

\section{Reliabilitas}

\section{Gambar 3. Path Diagram}

Sebelum memulai menganalisis model yang sebenarnya, tingkat signifikansi variabel model konseptual akan diuji. Instrumen reliabilitas dalam penelitian ini diukur dengan dua ISSN : 1979-7400 
kriteria yaitu nilai composite reliability dan cronbach's alpha. Hasilnya dapat dilihat dari tabel 3 di bawah ini.

Tabel 6 : Reliabilitas

\begin{tabular}{lcccc}
\hline \multicolumn{1}{c}{ Variabel } & $\begin{array}{c}\text { Cronbach's } \\
\text { Alpha }\end{array}$ & rho_A & $\begin{array}{c}\text { Composite } \\
\text { Reliability }\end{array}$ & $\begin{array}{c}\text { Average } \\
\text { Variance } \\
\text { Extracted } \\
\text { (AVE) }\end{array}$ \\
\hline Inklusi Keuangan & 0.787 & 0.792 & 0.877 & 0.705 \\
Keberlanjutan UMKM & 0.702 & 0.747 & 0.822 & 0.549 \\
Kinerja UMKM & 0.872 & 0.872 & 0.922 & 0.797 \\
Literasi Keuangan & 0.822 & 0.864 & 0.860 & 0.578 \\
\hline
\end{tabular}

Sumber: Hasil penelitian, diolah dengan Smart PLS 3.0, 2021

Hasil output tabel 6 menunjukkan bahwa composite reliability dan conbach's alpha dari semua konstruk bernilai lebih besar dari 0.70. maka dapat dikatakan bahwa reliabilitas semua konstruk dalam penelitian ini sudah baik dan menunjukan kesesuaian berdasarkan kriteria yang telah ditetapkan.

Validitas Diskriminan (Discriminant Validity)

Uji korelasi diskriminan dilakukan untuk melihat korelasi antara konstruk dengan konstruk lainnya. Tabel 7 menunjukan bahwa seluruh nilai kuadrat AVE lebih besar daripada korelasi antar dua variabel laten lainnya baik secara horizontal maupun vertikal. Nilai kuadrat AVE yang dimiliki juga menunjukkan nilai diatas 0.50. AVE dikatakan baik adalah ketika bernilai lebih besar dari 0.50 (Ghozali, 2016). Jika nilai akar kuadrat (square root of average) AVE setiap konstruk lebih besar daripada nilai korelasi antara konstruk dengan konstruk lainnya dalam model maka dapat disimpulkan bahwa konstruk memiliki tingkat validitas yang baik.

Tabel 7 : Nilai Discriminant Validity

\begin{tabular}{lcccc}
\hline & $\begin{array}{c}\text { Inklusi } \\
\text { Keuangan }\end{array}$ & Keberlanjutan & Kinerja & $\begin{array}{c}\text { Literasi } \\
\text { Keuangan }\end{array}$ \\
\hline Inklusi & $\mathbf{0 . 8 4 0}$ & & & \\
Keberlanjutan & 0.450 & $\mathbf{0 . 7 4 1}$ & & \\
Kinerja & 0.343 & 0.666 & $\mathbf{0 . 8 9 3}$ & $\mathbf{0 . 6 9 1}$ \\
Literasi & 0.256 & 0.263 & 0.498 & \\
\hline
\end{tabular}

Sumber: Hasil penelitian, diolah dengan Smart PLS 3.0, 2021

Pada tabel 7 perbandingan dari nilai akar AVE memperlihatkan bahwa dari masing-masing dari nilai tersebut lebih besar dibandingkan dengan korelasi antar variabel lainnya, sehingga dapat ditarik kesimpulan bahwa semua variabel laten dalam penelitian memiliki construct validity dan discriminant validity yang baik.

\section{Koefisien Determinan $\left(\mathbf{R}^{2}\right)$}

Pengujian structural model dilakukan untuk melihat hubungan antara konstruk, nilai signifikansi dan $R$ square dari model penelitian. Nilai $R$-square dapat digunakan untuk menilai pengaruh variabel independen tertentu terhadap variabel dependen. Nilai estimasi $R$-square dapat dilihat pada Tabel t dibawah ini.

Tabel 8 : Nilai $R$-Square

\begin{tabular}{lcc}
\hline & $\boldsymbol{R}$-Square & $\boldsymbol{R}$-square Adjusted \\
\hline Kinerja UMKM & 0.297 & 0.275 \\
Keberlanjutan UMKM & 0.226 & 0.201 \\
\hline
\end{tabular}

Sumber: Hasil penelitian, diolah dengan Smart PLS 3.0, 2021

Berdasarkan tabel 8 diketahui bahwa nilai $R$-square untuk variabel kinerja UMKM

ISSN : 1979-7400

E-ISSN: 2774-5163 
sebesar 0,297 yang dapat diinterpretasikan bahwa besarnya pengaruh variabel Inklusi Keuangan dan Literasi Keuangan terhadap Kinerja UMKM adalah 29.7\% sedangkan sisanya yaitu $71.3 \%$ dijelaskan oleh variabel lain di luar penelitian ini. Nilai $R$-square untuk variabel Keberlanjutan UMKM sebesar 0,226 yang artinya bahwa 22,6\% variabel Keberlanjutan UMKM dipengaruhi oleh Inklusi Keuangan dan Literasi Keuangan sedangkan sisanya sebesar $77.4 \%$ dipengaruhi oleh variabel lain di luar penelitian ini.

\section{Pengujian Hipotesis}

Diterima atau tidaknya sebuah hipotesis yang diajukan, perlu dilakukan pengujian hipotesis dengan menggunakan fungsi Bootstrapping pada SmartPLS 3.0. Hipotesis diterima pada saat tingkat signifikansi lebih kecil dari 0,05 atau $\mathrm{t}$-value melebihi nilai kritisnya (Hair et al., 2014). Nilai t statistics untuk tingkat signifikansi 5\% sebesar 1,96.

Tabel 9 : Hasil Path Analysis

\begin{tabular}{|c|c|c|c|c|c|}
\hline Hubungan & $\begin{array}{c}\text { Original } \\
\text { Sample (O) }\end{array}$ & $\begin{array}{c}\text { Sample } \\
\text { Mean (M) }\end{array}$ & T-Sta & $\begin{array}{c}P \text { - } \\
\text { Values }\end{array}$ & Hasil \\
\hline $\begin{array}{l}\text { Inklusi Keuangan -> } \\
\text { Keberlanjutan UMKM }\end{array}$ & 0.410 & 0.410 & 2.590 & 0.010 & Diterima \\
\hline $\begin{array}{l}\text { Inklusi Keuangan -> Kinerja } \\
\text { UMKM }\end{array}$ & 0.231 & 0.244 & 1.980 & 0.048 & Diterima \\
\hline $\begin{array}{l}\text { Literasi Keuangan -> } \\
\text { Keberlanjutan UMKM }\end{array}$ & 0.158 & 0.164 & 0.707 & 0.480 & Ditolak \\
\hline $\begin{array}{l}\text { Literasi Keuangan -> Kinerja } \\
\text { UMKM }\end{array}$ & 0.439 & 0.443 & 3.028 & 0.003 & Diterima \\
\hline
\end{tabular}

Sumber: Hasil penelitian, diolah dengan Smart PLS 3.0, 2021

Berdasarkan tabel 9 diatas, maka dapat diketahui pengujian hipotesis sebagaimana berikut ini:

\section{Pengujian Hipotesis 1}

Pada penelitian ini menyatakan bahwa Hipotesis 1 (H1) memberikan penjelasan inklusi keuangan berpengaruh terhadap keberlanjutan UMKM di Solo Raya. Berdasarkan pengujian yang dilakukan hipotesis 1 dapat diketahui bahwa nilai $P$-values sebesar 0,010 lebih kecil dari 0,050 maka hasil tersebut memberikan kesimpulan bahwa Hipotesis 1 (H1) diterima. Pada masa pandemi covid-19 terdapat pembatasan pergerakan aktivitas masyarakat mengakibatkan penurunan penjualan dan pendapatan UMKM. Tingkat inklusi keuangan yang baik pada pelaku UMKM membuat keputusan pengelolaan keuangan menjadi lebih efisien. Penerapan penjualan berbasis online membuat pendapatan yang diterima oleh pelaku UMKM masih diatas Break Even Point (BEP). Para pelaku UMKM yang kekurangan permodalan melakukan upaya untuk mendapatkan bantuan permodalan dari berbagai pihak (keluarga atau teman) dan mengupayakan restrukturisasi pinjaman diperbankan, sehingga upaya tersebut membuat UMKM dapat terus melakukan keberlanjutan usaha. Hasil penelitian ini sejalan dengan penelitian yang dilakukan sebelumnya pada UMKM Muslim dimana inklusi keuangan berpengaruh terhadap keberlanjutan UMKM (Nurohman et al., 2021). Penelitian lain yang sejalan dengan penelitian ini dilakukan oleh Aribawa (2016) dan Wise (2013).

\section{Pengujian Hipotesis 2}

Dalam penelitian ini menyatakan bahwa Hipotesis $2(\mathrm{H} 2)$ memberikan penjelasan inklusi keuangan berpengaruh terhadap kinerja UMKM di Solo Raya. Berdasarkan pengujian yang dilakukan pada Hipotesis 2 dapat diketahui bahwa nilai $P$-values sebesar 0,048 lebih kecil dari 0,050 maka hasil tersebut memberikan kesimpulan bahwa Hipotesis 2 (H2) diterima. Tingkat inklusi keuangan pada pelaku UMKM yang baik, membuat pelaku UMKM mampu mengelola keuangan lebih baik dibandingkan masa sebelum 
pandemi. Pemahaman keuangan yang baik menjadikan pelaku UMKM dapat melaksanakan usaha sesusai program yang telah ditetapkan. Pengelolaan keuangan sehingga biaya dapat lebih rendah dibandingkan masa sebelum pandemi, mampu meningkatkan kinerja UMKM yang menghasilkan pertumbuhan usaha. Program usaha yang disusun oleh UMKM juga mampu membuat permintaan meningkat dan sesuai keinginan pelanggan. Hasil penelitian ini sejalan dengan penelitian yang dilakukan oleh Septiani \& Wuryani (2020) yang menyatakan bahwa inklusi keuangan berpengaruh terhadap perkembangan kinerja UMKM di kawasan Sidoarjo. Penelitian lain yang sejalan dengan hasil penelitian ini dilakukan oleh Wulandari (2019) yang menyatakan bahwa inklusi keuangan berpengaruh signifikan terhadap kinerja UMKM Provinsi DKI Jakarta.

\section{Pengujian Hipotesis 3}

Pada penelitian ini menyatakan bahwa Hipotesis 3 (H3) memberikan penjelasan literasi keuangan berpengaruh terhadap keberlanjutan UMKM di Solo Raya. Berdasarkan pengujian yang dilakukan hipotesis 3 dapat diketahui bahwa nilai $P$-values sebesar 0,480 lebih besar dari 0,050 maka hasil tersebut memberikan kesimpulan bahwa Hipotesis 3 (H3) ditolak. Inflasi yang terjadi akibat keterbatasan ketersediaan barang dan jasa membuat pelaku UMKM sulit untuk melakukan kegiatan investasi dalam upaya meningkatkan keuangan dimasa depan. Investasi yang kurang tepat dimasa pandemi covid-19 dapat mengakibatkan risiko yang tinggi terutama berkaitan dengan keuangan dan keberlanjutan UMKM. Pelaku UMKM cenderung menunggu situasi kembali normal untuk membuat keputusan usaha yang berisiko tinggi terutama berkaitan dengan investasi dimasa depan. Hal ini mengakibatkan literasi keuangan tidak berpengaruh terhadap keberlanjutan usaha, karena pelaku UMKM dihadapkan pada persoalan yang tidak berkaitan dengan pemahaman keuangan secara langsung seperti kebijakan pembatasan kegiatan yang dilakukan oleh masyarakat.

\section{Pengujian Hipotesis 4}

Dalam Hipotesis 4 (H4) menyatakan bahwa literasi keuangan berpengaruh terhadap kinerja UMKM. Berdasarkan pengujian Hipotesis 4 (H4) yang dilakukan dalam penelitian ini dapat diketahui bahwa nilai $P$-values sebesar 0,003 lebih kecil dari 0,050 maka hasil tersebut memberikan kesimpulan bahwa Hipotesis 4 (H4) diterima. Pengetahuan pelaku UMKM tentang produk perbankan membuat pekerjaan yang dilakukan selalu terencana dan berjalan sesuai program kerja. Kesalahan kerja atau ketidaktepatan keputusan yang dilakukan dimasa lalu oleh pelaku UMKM tidak terjadi kembali karena pengetahuan keuangan yang dimiliki. Pelaku UMKM akan menggunakan produk pembiayaan ketika dirasa usaha yang berjalan tidak berada dalam posisi berisiko tinggi. Hasil penelitian ini sejalan dengan penelitian yang dilakukan oleh Septiani \& Wuryani (2020) dalam penelitian yang dilakukan pada UMKM di Sidoarjo dan Wulandari (2019) dengan penelitian yang dilakukan di Provinsi DKI memiliki hasil bahwa literasi keuangan berpengaruh terhadap kinerja UMKM.

\section{PENUTUP}

Penelitian dilakukan untuk menguji pengaruh inklusi keuangan dan literasi keuangan terhadap keberlanjutan usaha dan kinerja UMKM di Solo Raya. Hasil yang diperoleh menunjukan bahwa inklusi keuangan berpengaruh terhadap keberlanjutan usaha dan kinerja keuangan UMKM, serta literasi keuangan berpengaruh terhadap kinerja keuangan pada UMKM di Solo Raya. Sedangkan variablel literasi keuangan tidak berpengaruh terhadap keberlanjutan usaha pada UMKM di Solo Raya. Hasil penelitian

ISSN : 1979-7400

E-ISSN: 2774-5163 
ini juga menunjukan bahwa semakin tinggi literasi keuangan maka akan semakin tinggi pula kinerja keuangan dan keberlanjutan UMKM dimasa mendatang. Pelaku usaha yang memahami keuangan mampu membuat kinerja usaha lebih baik dan membuat UMKM mengalami keberlanjutan usaha.

Penelitian yang telah dilakukan memiliki keterbatasan sehingga diharapkan bagi peneliti berikutnya diharapkan dapat mengembangkan model penelitian tentang pengembangan UMKM melalui melalui keberlanjutan usaha dan peningkatan kinerja usaha serta menggunakan variabel lain yang memengaruhi perkembangan UMKM. Pengujian pada wilayah yang lebih luas perlu dilakukan untuk mengetahui kondisi UMKM mengingat Indonesia terbagi menjadi beberapa wilayah sehingga sangat dimungkinkan ditemukan variabel berbeda yang memengaruhi kondisi keberlanjutan dan kinerja UMKM.

\section{DAFTAR PUSTAKA}

Ali. (2003). Performance Measurement Framework for a Small and Medium Enterprise. University of Alberta Disertation.

Aribawa. (2016). Pengaruh Literasi Keuangan Terhadap Kinerja dan Keberlangsungan UMKM di Jawa Tengah. Jurnal Siasat Bisnis, 20 No. 1.

Bahtiar, R. A., \& Saragih, J. P. (2020). Dampak Covid-19 Terhadap Perlambatan. Kajian Singkat Terhadap Isu Aktual Dan Strategis, 12, 20.

Bank Indonesia, D. P. A. K. dan U. (n.d.). Booklet Keuangan Inklusif. Bank Indonesia.

BPS. (2021). Februari 2021: Tingkat Pengangguran Terbuka (TPT) sebesar 6,26 persen. Journal of Chemical Society. https://www.bps.go.id/pressrelease/2021/05/05/1815/februari-2021--tingkatpengangguran-terbuka--tpt--sebesar-6-26-persen.html

Desiyanti, R. (201 C.E.). Literasi dan Inklusi Keuangan serta Indeks Utilitas UMKM di Padang. BISMAN Jurnal Bisnis \& Manajemen, 2(2), 122-.

Development., O. for E. C. (2016). Measuring Financial Literacy: Questionnaire and Guidance Notes for Conducting an Internationally Comparable Survey of Financial Literacy. INFE.

Ghozali. (2016). Aplikasi Analisis Multivariate (8th ed.). Badan penerbit Universitas Diponegoro.

Hilmawati, M. R. N., \& Kusumaningtias, R. (2021). INKLUSI KEUANGAN DAN LITERASI KEUANGAN TERHADAP KINERJA DAN KEBERLANGSUNGAN SEKTOR USAHA MIKRO KECIL MENENGAH. Nominal: Barometer Riset Akuntansi Dan Manajemen, 10(1), 135-152. https://doi.org/10.21831/nominal.v10i1.33881

Hudson, M., A. S. and M. B. (2001). Theory and practice in SME performance measurement systems. International Journal of Operations \& Production Management., 21(8). 109.

Huston, S. J. (2010). Measuring financial literacy. Journal of Consumer Affairs, 44 (2).

INFE, O. (2012). PISA 2012 Literacy assessment framework.

Irmawati. (2013). Model Inklusi Keuangan Pada Umkm Berbasis Pedesaan. JEJAK: Jurnal Ekonomi Dan Kebijakan, 6(2). https://doi.org/10.15294/jejak.v6i2.3885

Julaika, H. (2020). Kontribusi ke PDB hingga 60\% UMKM Terus Digenjot. Media Indonesia. $\quad \mathrm{https} / / /$ mediaindonesia.com/nusantara/340785/kontribusi-ke-pdbhingga-60-umkm-terus-digenjot

Keuangan, O. J. (2017). Strategi Nasional Literasi Keuangan Indonesia. Otoritas Jasa ISSN : 1979-7400

E-ISSN: 2774-5163 


\section{Keuangan.}

Klapper, S.-A. J. (n.d.). The Little Data Book on Financial Inclusion.

Le, T.-H., Chuc, A. T., \& Taghizadeh-Hesary, F. (2019). Financial inclusion and its impact on financial efficiency and sustainability: Empirical evidence from Asia. Borsa Istanbul Review, 19(4), 310-322. https://doi.org/10.1016/j.bir.2019.07.002

Lusardi, A \& Mitchell, O. S. (2007). (2007). "Baby Boomer Retirement Security: The Roles of Planning, Financial Literacy, and Housing Wealth". Journal of Monetary Economics, 54(1), 2.

Malik, A. (2021). OJK: Generasi Milenial Paling Terdampak Pandemi, Literasi Keuangan Makin Krusial. Bareksa.Com.

Nurohman, Y. A., Kusuma, M., \& Narulitasari, D. (2021). Fin-Tech, Financial Inclusion, and Sustainability: a Quantitative Approach of Muslims SMEs. International Journal of Islamic Business Ethics, 6(1), 54. https://doi.org/10.30659/ijibe.6.1.5467

OJK. (2020). Survei Nasional Literasi dan Inklusi Keuangan 2019. OJK.

Rapih, R. (2016). Pendidikan Literasi Keuangan pada Anak: Mengapa dan Bagaimana? Scholaria, Vol. $6 \mathrm{~N}$.

Republika. (2021). BI Solo Dorong Literasi Keuangan Warga Girilayu Karanganyar. Republika. $\quad$ https://republika.co.id/berita/qusrow327/bi-solo-dorong-literasikeuangan-warga-girilayu-karanganyar

Sanistasya, P. A., Raharjo, K., \& Iqbal, M. (2019). The Effect of Financial Literacy and Financial Inclusion on Small Enterprises Performance in East Kalimantan. Jurnal Economia, 15(1), 48-59. https://doi.org/10.21831/economia.v15i1.23192

Santika, Z. D., \& Maulana, M. A. (2020). Penurunan pendapatan UMKM akibat Covid19. Prosiding Seminar Nasional Penalaran Dan Penelitian Nusantara, 1, 150-159.

Septiani, R. N., \& Wuryani, E. (2020). Pengaruh Literasi Keuangan Dan Inklusi Keuangan Terhadap Kinerja Umkm Di Sidoarjo. E-Jurnal Manajemen Universitas Udayana, 9(8), 3214. https://doi.org/10.24843/ejmunud.2020.v09.i08.p16

Soetjipto, N. (2020). Ketahanan UMKM Jawa Timur Melintasi Pandemi Covid-19. KMedia. http://repository.stieyapan.ac.id/id/eprint/73/

Sugiyono. (2016). Metode Penelitian Kuantitatif, Kualitatif, dan R\&D. Alfabet.

Tempo. (2021). Gonta-ganti Istilah Penanganan Covid-19: PSBB Hingga Terkini PPKM Level 4. Tempo. https://nasional.tempo.co/read/1486390/gonta-ganti-istilahpenanganan-covid-19-psbb-hingga-terkini-ppkm-level-4/full\&view=ok

Thaha, A. F. (2020). Dampak Covid-19 Terhadap UMKM di Indonesia. Jurnal Brand, 2(1), 147-153.

Wickham, P. A. (2006). Strategic Entrepreneurship, 4th Edition.

Wise, S. (2013). The Impact of Financial Literacy on New Venture Survival. International Journal of Business and Management, 8(23). https://doi.org/10.5539/ijbm.v8n23p30

Wulandari, R. (2019). Pengaruh Literasi Keuangan dan Inklusi Keuangan terhadap Kinerja UMKM (Studi Kasus pada UMKM Provinsi DKI Jakarta). Skripsi Fakultas Ekonomi Dan Bisnis UIN Syarif Hidayatullah, 1-114. 